\title{
The Case-law of the ECtHR on the Right to an Independent and Impartial Tribunal
}

The case-law of the ECtHR on the right to a fair trial provides that a "tribunal" is compatible with the requirements of the ECHR when (1) it is established by law, (2) it is independent and (3) it is impartial. This section provides a detailed analysis of these concepts.

\subsection{Established by Law}

Article 6(1) ECHR requires that all disputes involving the determination of "civil rights and obligations" or of "criminal charges" be settled by a tribunal "established by law". This is a general requirement that deals both with issues of hierarchy in constitutional law and with the quality of the law. However, the ECtHR has consistently stated that it does not impose on the member states any constitutional arrangements.

First of all, the established-by-law procedure requires that tribunals be established by a Constitution or by a law. Thus, in the early case Zand, the applicant - who was involved in an employment dispute - argued that the labour court assigned to decide his case was not a tribunal fulfilling the conditions enshrined in Article 6(1) ECHR due to the fact that it was established by a governmental decree, not by a law. The applicant complained in particular about the fact that a labour court could be established and removed by an administrative decision based on temporary needs.

The Commission recalled that the object of the term "established by law" in Article 6(1) ECHR was to ensure "that the judicial organisation in a democratic society did not depend on the discretion of the executive, but that it was regulated by law emanating from Parliament". ${ }^{1}$

In a more recent case, Savino and Others, the Court was faced with the question of whether or not the internal judicial bodies operating employment-related

1 ECtHR. Zand v. Austria, application no. 736o/76, judgement on 16 May 1977, pp. 70 and 8o. 
disputes within the Italian Chamber of Deputies were established by law as required by Article 6(1) ECHR. ${ }^{2}$

The Court noted first of all that its goal is not "to impose upon the States a constitutional model concerning the relationship and interaction of different State powers. The choice of the Italian legislator to preserve the autonomy and independence of the Parliament from the ordinary jurisdiction does not raise as such an issue before the Court". ${ }^{3}$

The Court noted that as a matter of principle, delegation of judicial power is acceptable if it is provided for by the constitution of the state concerned. ${ }^{4}$ The Court concluded that, since the judicial bodies within the Italian Chamber of Deputies were established on the basis of secondary legislation which had its source in the Italian Constitution, they were established by law as required by the right to a fair trial.

In relation to the establishment of specialized courts, such as the Constitutional Court or the Board of Visitors, the court found that they are compatible with Article 6(1) ECHR if they are established and are endowed by the law with the judicial function of adjudicating cases. ${ }^{56}$ The Court emphasised that the word "tribunal" in Article 6(1) ECHR "is not necessarily to be understood as signifying a court of law of the classic kind, integrated within the standard judicial machinery of the country".7 However, the specialized nature of a tribunal should not prevent it from displaying the following requirements: independence from the executive and the parties, guaranteed duration of its members' term of office, and guarantees afforded by its procedure. ${ }^{8}$

Thus, in a case concerning the right to periodic review of detention in mental health institutions, it was established that mental health review tribunals comply with the requirements of the right to a fair trial when they are independent and when sufficient procedural safeguards are in place. The Court stressed that an important feature of a tribunal "established by law" is jurisdiction to decide the lawfulness of a detention and to order release. In case

2 ECtHR. Savino and Others v. Italy, applications nos. 17214/05, 20329/o5 and 42113/o4, judgement of 28 Apr 2009 .

3 Savino and Others v. Italy, quoted above, paragraph 92.

4 Savino and Others $v$. Italy, quoted above, paragraph 94.

5 ECtHR. Crociani and Others v. Italy, application nos. 8603/79, 8722/79, 8723/79, 8729/79, judgement 18 dec 1980 .

6 ECtHR. Campbell and Fell v. the United Kingdom, application nos. $7819 / 77$ and $7878 / 77$, judgement of 28 Jun 1984.

7 Campbell and Fell v. the United Kingdom, quoted above, paragraph 76 .

8 ECtHR. Le Compte, Van Leuven and De Meyere v. Belgium, application nos. 6878/75 and 7238/ 75 , judgement of 23 Jun 1981, paragraph 55 . 
a tribunal has only advisory functions, it cannot be deemed to be a tribunal "established by law". 9

At the same time, as one author noted, the established-by-law requirement has been interpreted by the Court in respect of other provisions "as imposing also a certain quality of the relevant law". ${ }^{10}$ Thus, in a case that concerned the taking into care of the applicants' three children by social services, the Court held that "in accordance with the law" does not "merely refer back to domestic law but also relates to the quality of the law, requiring it to be compatible with the rule of law; it thus implies that there must be a measure of protection in domestic law against arbitrary interferences by public authorities with the rights safeguarded".11

\subsection{Independence}

The ECtHR has a rich case-law on the issue of the independence of justice, dealing with the organisation of ordinary courts, specialised tribunals and administrative courts. The case-law concerning independence of tribunals described in this section deals with (1) the duty not to intervene with the functioning of the judicial branch; (2) the cumulation of functions; (3) the principle that justice should not only be done but should also appear to be done and (4) the safeguards that can compensate for a lack of independence.

\subsubsection{Interference}

The first and most obvious corollary concerning the independence of justice is that tribunals should be free from the interference of the other branches of the government. A second is that the tribunals should be free from internal interference, from within the judicial branch as well.

Thus, in a few cases against Ukraine, the applicants complained about the interference of state authorities with the applicants' proceedings. The ECtHR noted first of all that, indeed, various state bodies, including the Prime Minister and the President of Ukraine, intervened in an open, persistent and sometimes blatant manner in the applicants' proceedings. The Court established to be of

$9 \quad$ ECtHR. $X v$. the United Kingdom, application no. 7215/72, judgement of 5 November 1981, paragraph 61 .

10 Loucaides, Loukis G. The European Convention on Human Rights: Collected Essays. Leiden: Martinus Nijhoff Publishers, 2007, p. 214.

11 ECtHR. Olsson v. Sweden (no. 1), application no. 10465/83, judgement of 24 Mar 1988, paragraph 61 . 
no importance "whether the impugned interventions actually affected the course of the proceedings. Coming from the executive and legislative branches of the State, they reveal a lack of respect for the judicial office itself and justify the applicant company's fears as to the independence and impartiality of the tribunals". ${ }^{2}$

The Court emphasized that the scope of the state's obligation to ensure a trial by an independent and impartial tribunal also

implies obligations on the executive, the legislature and any other State authority, regardless of its level, to respect and abide by the judgments and decisions of the courts, even when they do not agree with them. Thus, the State's respecting the authority of the courts is an indispensable precondition for public confidence in the courts and, more broadly, for the rule of law. ${ }^{13}$

The ECtHR stressed, however, that in order to respect the above-mentioned principle, "the constitutional safeguards of the independence and impartiality of the judiciary do not suffice. They must be effectively incorporated into everyday administrative attitudes and practices".14

In the case Khrykin the applicant was involved in an employment dispute. ${ }^{15}$ He complained that the first-instance court lacked independence because of the pressure exercised by the President of the Regional Court that resulted in the re-opening of his case and quashing of the final judgement in his favour.

The Court held that the independence of the judiciary is only possible when individual independence exists alongside the institutional independence, working together towards impartial decision making. Thus, independence of the judiciary "characterizes both a state of mind and a set of institutional and operational arrangements. The former is concerned with the judge's impartiality and the latter with defining relations with other bodies, in particular other state powers". 16 The Court also noted that judicial independence required that those judged "be free from instructions or pressures from the fellow judges and vis-à-vis their judicial superiors". ${ }^{17}$

12 ECtHR. Sovtransavto Holding v. Ukraine, application no. 48553/99, judgement of $25 \mathrm{Jul}$ 2002, paragraph 8 o.

13 ECtHR. Sovtransavto Holding v. Ukraine, quoted above.

14 ECtHR. Agrokompleks v. Ukraine, application no. 23465/o3, judgement of 6 Oct 2011.

15 ECtHR. Khrykin v. Russia, application no. 33186/o8, judgement of 19 Apr 2011.

16 Khrykin v. Russia, quoted above, paragraphs 28-29.

17 Khrykin v. Russia, quoted above, paragraphs 28-29. 
In the case Parlov-Tkalcic the Court added that internal judicial independence required that judges "be free from directives or pressures from the fellow judges or those who have administrative responsibilities in the court such as the president of the court or the president of a division in the court". ${ }^{18}$ The Court highlighted a few institutional characteristics to be taken into account when performing such analysis. First, it is important that the managerial functions are clearly separated from the judicial functions, so that the managers could not influence the composition of the panels, the way files were distributed between panels or their outcomes. ${ }^{19}$ Also, it is important to limit the powers of the hierarchically superior judged over career advancement or discipline of their subordinates. ${ }^{20}$

\subsubsection{Cumulation of Functions}

Closely linked to the idea that justice is independent when it is free from external and internal pressure is the argument that the cumulation of functions is detrimental to the independence of justice. The increased amount of litigation in Europe and the omnipresence of the administration in the public life can produce conditions in which the government acts both as a party and as the decision-maker in a case. According to the ECtHR, such arrangements are not compatible with the independence of justice as required by Article 6(1) ECHR.

One of the early authorities on this subject is the De Cubber case in which the applicant was prosecuted and convicted for theft. He complained that the investigative and the trial judge in this case were one and the same person. ${ }^{21}$

The Court noted that, under the Belgian law, the investigating judge was subordinate to the prosecutor and had wide-ranging investigative powers. Also, the investigation was inquisitorial and secret, and not conducted in the presence of both parties. The Court also noted that one might understand the unease that an accused can feel when he observes that the person sitting on the bench to hear his case has intensely interrogated him during the investigation, ordered his detention on remand or taken other investigative measures in his/her case.

The Court argued that

through the various means of inquiry which he will have utilised at the investigation stage, the judge in question, unlike his colleagues, will

18 ECtHR. Parlov-Tkalcic v. Croatia, application no. 24810/o6, judgement of 22 Dec 2009, paragraph 86.

19 Parlov-Tkalcic v. Croatia, quoted above, paragraphs 88-9o.

20 Parlov-Tkalcic v. Croatia, quoted above, paragraphs 91-93.

21 De Cubberv. Belgium, quoted above. 
already have acquired well before the hearing a particularly detailed knowledge of the - sometimes voluminous - file or files which he has assembled. Consequently, it is quite conceivable that he might, in the eyes of the accused appear, firstly, to be in a position to enable him to play a crucial role in the trial court and, secondly, even to have a pre-formed opinion which is liable to weigh heavily in the balance at the moment of the decision. ${ }^{22}$

The Court found such an arrangement to be incompatible with the right to a fair trial and concluded furthermore that such defects cannot be cured by subsequent appeal courts. ${ }^{23}$

In another case, this time against the United Kingdom, the applicant complained about the independence of the court martial that sat in the criminal case initiated against him. ${ }^{24} \mathrm{Mr}$ Findlay argued that all appointed officers were subordinate to the convening officer who acted as a prosecutor in his case. Furthermore, the applicant argued that the officers lacked the necessary legal background or experience that would support them in acting as an independent or impartial tribunal.

The Court noted that the convening officer performed important prosecutorial tasks before the beginning of the applicant's court proceedings. He had (1) decided which charges should be brought against the applicant, (2) decided which type of court martial was the most appropriate for the applicant's case, (3) convened the court martial, (4) appointed the members of the court martial, the prosecuting and the defending officers, (5) sent an abstract of the evidence to the prosecuting officer and the judge advocate, and (6) procured the attendance of witnesses for the prosecution. He was also involved in the establishment of the charge.

The Court found that the fact that all members of the court martial were subordinate in rank to the convening officer might have raised serious doubts as to the independence of the court. Even more, the Court found incompatible with fair trail principles the fact that the convening officer also acted as a confirming officer. Under the rules in place in the United Kingdom at the time, the decision reached by the court martial would only become binding if the convening officer confirmed it. ${ }^{25}$

22 De Cubber v. Belgium, quoted above, paragraph 29.

23 De Cubber v. Belgium, quoted above, paragraph 33.

24 ECtHR. Findlayv. the United Kingdom, application no. 22107/93, judgement of 25 Feb 1997.

25 Findlay $v$. the United Kingdom, quoted above, paragraph 77. 
Considering that none of the existing guarantees - including the involvement of the judge advocate and judicial review - could correct the defects concerning the independence of the court martial, the Court concluded that the court martial was not an independent tribunal and found a violation of Article 6(1) ECHR.

In Benthem, the applicant intended to open a gas station for motorcycles. He was initially granted a license by the municipal authorities. ${ }^{26}$ However, upon appeal by the Health Inspector, the Administrative Litigation Division issued an opinion recommending that the license be refused; a draft of the decree to be adopted was attached thereto. By a decree in the same terms as the draft, the Crown quashed the municipal authorities' decision to issue a license for the applicant.

The applicant complained that his case has not been heard by an independent and impartial tribunal, but by administrative authorities that did not fulfil the criteria required by Article 6(1) ECHR. First, as to the Administrative Litigation Division, the Court noted that, despite its name and the appearances, the division was not a tribunal for the purposes of Article 6, as it lacked the power to adopt binding decisions. ${ }^{27}$

As for the Crown, the Court noted first that it was the head of the executive. Second, the Court stressed that the Crown operated by means of royal decrees that were - as form and substance - administrative acts that emanated from the government. Lastly, the Court noted that the royal decrees could not be challenged by means of judicial review as required by Article 6(1) ECHR. ${ }^{28}$

In Beaumartin, the applicants' shares of a Moroccan company had been expropriated. ${ }^{29}$ France and Morocco concluded an international treaty that obliged Morocco to pay France compensation in a single lump sum and France to distribute it to the citizens who had lost their assets in Morocco. The applicants lodged a compensation request with the committee appointed for this purpose. The committee comprised representatives of the following ministries: Ministry of Foreign Affairs, Ministry of Justice, Ministry of Interior and Ministry of Economy. The committee issued a decision compensating the applicants only partially. They therefore challenged this decision before the Conseil d'Etat.

The Conseil d'Etat requested instructions from the Ministry of Foreign Affairs concerning the way in which the Franco-Moroccan treaty should be

26 ECtHR. Benthem v. the Netherlands, application no. 8848/80, judgement of 23 Oct 1985 .

27 Benthem v. the Netherlands, quoted above, paragraph 40.

28 Benthem v. the Netherlands, quoted above, paragraphs 41-43.

29 ECtHR. Beaumartin v. France, application no. 15287/89, judgement of 24 Nov 1994. 
interpreted in the applicants' case. The Ministry of Foreign Affairs replied that the applicants had correctly received only partial compensation for their assets and that the treaty at issue did not allow for a different interpretation. Consequently, the Conseil d'Etat dismissed the applicants' case on the grounds that the interpretation it received from the Ministry of Foreign Affairs was binding on it and could not be departed from. The Court noted that, despite the fact that in the meantime, France had changed its legislation, at the relevant time the domestic courts did not have jurisdiction to interpret international treaties. The Court noted that the nature of the proceedings was such that the applicants had as their opponent the Ministry of Foreign Affairs, which was also one of the issuing parties of the decision that the applicants were challenging. In addition, the applicants had no means of challenging the Ministry's involvement in the proceedings, nor the referral procedure by which the Conseil d'Etat asked for instructions the Ministry of Foreign Affairs. ${ }^{30}$ The Court concluded that, in the view of the Ministry's involvement in the proceedings at issue, the Conseil d'Etat could not be deemed to be an independent tribunal.

In a case against Italy, the Court was called to decide if the Commission of the Chamber of Deputies was an independent and impartial tribunal. ${ }^{31}$ In that case, the applicants held different administrative positions in the Chamber of Deputies. They sued their employer concerning a recruitment opportunity. They complained that the Human Resources Commission of the Chamber of Deputies that was called to decide their trial was not an independent and impartial tribunal established by law. The Court agreed with the applicants and stressed that independent and impartial tribunals played an important role in every democracy because they inspire confidence in the public. ${ }^{32}$

In a few French cases, the Court was faced with the question of independence of specialized courts. In Didier, the applicant had been sanctioned during disciplinary proceedings initiated by the Financial Markets Board (Conseil des marchés financiers - FMB). The FM B ordered the suspension of the applicant's trade license for six months and the payment of a fine of 5,000,000 French francs. The applicant complained about the fact that the rapporteur who investigated his case participated in the deliberations. ${ }^{33}$ The Court stated that in order to assess if the concomitant exercise of investigative and decisionmaking functions by the same person respect the principle of impartiality, a

30 Beaumartin v. France, quoted above, paragraph 38.

31 Savino and Others v. Italy, quoted above.

32 Savino and Others v. Italy, quoted above, paragraph 105.

33 ECtHR. Didier v. France, application no. 58188/oo, judgement of 27 Aug 2002. 
detailed analysis of the tasks performed needs to be undertaken. The Court noted that in the case at issue, the rapporteur has been investigating the applicant's case upon appointment by the Financial Markets Board, but that he has not been involved in formulating the charges against the applicant. The Court noted that "bias is excluded when a judge does not bring charges despite his in-depth knowledge of the case". ${ }^{34}$ The Court added that as the rapporteur was not involved in the formulation of the charges, he was not competent to close a case or to extend the object of the investigation. Instead, his duty was to check the facts and to report in writing on the results of his investigation. The Court concluded that the preliminary assessment performed by the rapporteur during the hearing did not endanger the principle of impartiality since the accused would have an opportunity to react and to have the last word. ${ }^{35}$

A different conclusion was reached by the Court in another case against France, where the applicant - an investment fund - complained about the dependence and the mpartiality of the French Banking Commission that had initiated disciplinary proceedings against the applicant and issued a blame for failing to respect the existing legal provisions. ${ }^{36}$ The applicant complained in particular about the Banking Commission's concomitant exercise of administrative and adjudicatory functions.

The Court observed that the French Banking Commission exercised two types of functions: first, a control function that encompassed both administrative control and injunction power and on the basis of which the Banking Commission could issue preventive measures, recommendations or injunctions; and second, a disciplinary function that enabled the Banking Commission to issue sanctions and which, for this purpose, rendered it an administrative adjudicator (jurisdiction administrative). ${ }^{37}$ The Court highlighted in particular the "lack of precision of the legal texts that describe the procedure before the Banking Commission, especially concerning the composition and the functions of the organs called to exercise the different functions entrusted to it".38 More precisely, there was no internal regulation separating the prosecution, taking of evidence and adjudication of the case before the Banking Commission. On the contrary, the Banking Commission initiated the proceedings, performed the investigation, acted as the accusing party during the oral hearing and finally sanctioned the applicant. Under such circumstances, the

34 Didier v. France, quoted above, p. 7.

35 Didier v. France, quoted above, p. 8.

36 ECtHR. Dubus S.A. v. France, application no. 5242/04, judgement of 11 Jun 2009.

37 Dubus S.A. v. France, quoted above, paragraph 55.

38 Dubus S.A.v. France, quoted above, paragraph 56. 
applicant's doubts as to the Banking Commission' impartiality were objectively justified. ${ }^{39}$

The Court raised an interesting point concerning the Banking Commission's power to initiate its own investigations (faculté d'auto-saisine). Without questioning its legality, the Court highlighted, however, that the power to initiate its own investigations must be subordinated to the principle of impartiality: "it is necessary to define with clarity the power to initiate investigations ex officio, in such a way that the impression that the guilt of the applicant had already been established from the opening of the proceedings themselves be erased".40

In Sigma Radio Television, the applicant complained about the cumulation of functions in prosecuting, investigating, trying and deciding cases and imposing sanctions of the Cyprus Radio and Television Authority (CRTA). ${ }^{41}$ In addition, the applicant complained that the members and staff of the CRTA had a direct and personal interest in imposing fines as the amounts thus collected were deposited in the CRTA's Fund from which their salaries and remuneration were paid. The Court found that despite the existence of safeguards, the combination of different functions of the CRTA and, in particular, the fact that all fines are deposited in its own fund for its own use, gave rise to legitimate concerns that the CRTA lacked the necessary structural impartiality to comply with the requirements of Article $6 .{ }^{42}$

\subsubsection{Appearances}

One of the most important theories developed by the ECtHR to assess the independence and impartiality of courts is the theory of appearances. The theory of appearances - which is an application of the adage justice must not only be done, but also seen to be done - was first developed in relation to the principle of impartiality and later extended to the principle of independence. ${ }^{4344}$

In Delcourt, the Court was faced with the question of whether or not the Belgian Court of Cassation was independent in light of the fact that a member of the Procureur général's department participated in secret deliberations during the applicant's criminal proceedings. ${ }^{45}$

\footnotetext{
39 Dubus S.A.v. France, quoted above, paragraphs 59-62.

40 Dubus S.A.v. France, quoted above, paragraph 6o.

41 ECtHR. Sigma Radio Television Ltd. v. Cyprus, applications nos. 32181/04 and 35122/o5, judgement of 21 Jul 2011.

42 Sigma Radio Television Ltd. v. Cyprus, quoted above, paragraph 150.

43 See ECtHR. Hauschildt v. Denmark, application no. 10486/83, judgement of 24 May 1989.

44 ECtHR. Kleyn and others $v$. the Netherlands, application nos. 39343/98, 39651/98, 43147/98, 46664/99, judgement of 6 May 2003, paragraph 192, in which the Court indicated that the notion of independence and objective impartiality are closely linked.

ECtHR. Delcourt v. Belgium, application no. 2689/65, judgement of 17 Jan 1970.
} 
The Court first noted the unusual and unique - among the member states of the Council of Europe - character of the Belgian system. The Court also acknowledged that an accused who sees a member of the Procureur général's department accusing them in open court and then leaving the courtroom with the judges for secret deliberations, might have serious doubts as to the independence of the court. ${ }^{46}$ The Court stressed, however, that while appearances were important, they were not decisive.

The Court pointed out that the Belgian system was constructed in such a way as to exclude the influence of the Minister of Justice on the Procureur général's department acting within the Court of Cassation. At the same time, the Procureur général's department within the Court of Cassation could guide the public prosecutors from the lower courts only in matters of doctrine, excluding thus the possibility of giving guidance concerning case-handling. Second, the Procureur général was not an accusing party during criminal proceedings, its role being to safeguard the interests of the society. During the deliberations, the Procureur général "upholds a different interest, that which is concerned with the observance by the judges of the law and not with the establishment of the guilt or innocence of the accused". ${ }^{47}$ Lastly, the Court highlighted that "the Procureur général's department at the Court of Cassation is an adjunct and an adviser of the Court; it discharges a function of a quasi-judicial nature. By the opinions which it gives according to its legal conscience, it assists the Court to supervise the lawfulness of the decisions attacked and to ensure the uniformity of judicial precedent". 48

The Court concluded its argument in favour of the Belgian system with an unusual argument. It stated that, despite it being unique among the Member States of the Council of Europe, it was a legitimate system. Its legitimacy stemmed from the fact that the system existed for more than one and a half century from the fact that the Belgian Parliament has twice considered but maintained it. The Court seemed furthermore impressed by the fact that neither the legal professions, nor the public opinion tried to challenge this judicial system. ${ }^{49}$ The Court concluded that, despite the Procureur général's participation in the deliberations during the applicant's case, the criminal proceedings against him were not biased.

In the Campbell and Fell case, the applicants were sanctioned disciplinarily for breaches of prison discipline in an incident that involved both them and

46 Delcourt v. Belgium, quoted above, paragraph 3 .

47 Delcourt v. Belgium, quoted above, paragraph 33.

48 Delcourt v. Belgium, quoted above, paragraph 34.

49 Delcourt v. Belgium, quoted above, paragraph 36. 
prison guards. The Board of Visitors punished them with a total of approximately 570 days' loss of remission. As a result, they were released from prison almost two years later than their initial prison sentence. The applicants claimed that the Board of Visitors was not an independent tribunal within the meaning of Article 6(1) ECHR in that it was appointed and guided by the Home Secretary and was under the control of the prison authorities who were involved in the incident.

The fact that the Board of Visitors was appointed and received guidelines from the Home Office was of little importance to the Court since the members were appointed for only three years, they were unpaid and did not receive guidelines concerning the performance of their adjudicatory functions. The Court remained unimpressed by the lack of any rules concerning the irremovability of the members of the Board or by the lack of separation between its supervisory and adjudicatory functions. The Court did not analyse the existing institutional overlap of these functions, but merely pointed that "the impression which prisoners may have that Boards are closely associated with the executive and the prison administration is a factor of greater weight".50 However, the Court concluded by a majority that there has been no violation of Article 6(1) ECHR because "the existence of such sentiments on the part of inmates, which is probably unavoidable in a custodial setting", was not sufficient to establish a lack of independence. ${ }^{51}$

In another case, the applicant, Mrs Belilos, had taken part in an unauthorized street demonstration following which a police officer imposed a fine on her. ${ }^{52}$ The applicant challenged the fine first before the Police Board. The Police Board found that the facts had been established correctly and that the legal qualification and the fine were correctly assessed. The applicant brought further proceedings seeking to declare void the fine and the criminal proceedings against her before the Criminal Cassation Division of the Vaud Cantonal Court. The latter, however, dismissed the applicant's action because it had only a limited jurisdiction over fines imposed by the Police Board. The same conclusion was reached by the Federal Court upon public law appeal proceedings.

The applicant complained that the Police Board was not an independent tribunal within the meaning of the Article 6(1) ECHR. The Police Board was an administrative body formed of one policeman that would be necessarily biased when called to review the sanctions imposed by his/her colleagues.

$5^{\circ}$ Campbell and Fell $v$. the United Kingdom, quoted above.

$5^{1}$ Campbell and Fell v. the United Kingdom, quoted above, paragraphs 79-82.

$5^{2}$ ECtHR. Belilos v. Switzerland, application no. 10328/83, judgement of 29 Apr 1988. 
The Court first analysed the status of the Police Board in Swiss legislation and case-law. As it appeared, the relevant laws considered the Police Board a "municipal authority". Furthermore, the Federal Court described the Police Board in its judgments as an "administrative authority", term that has been employed by the Swiss Government in its submissions before the Court in Strasbourg. ${ }^{53}$ Second, the Court emphasized the importance of appearances in cases such as that brought by the applicant. The Court pointed out that "the member of the Police Board is a senior civil servant who is liable to return to other departmental duties. The ordinary citizen will tend to see him as a member of the police force subordinate to his superiors and loyal to his colleagues. A situation of this kind may undermine the confidence which must be inspired by the courts in a democratic society". 54

In a number of Turkish cases, the issue of the independence of military tribunals has been considered. In Ergin, the applicant published an article arguing against mandatory military service. ${ }^{55} \mathrm{He}$ was then prosecuted and convicted by the Turkish Military Court. The ECtHR found that only in exceptional cases can civilians be convicted by the military courts and only in the presence of serious guarantees. ${ }^{56}$

The Court noted that both in the Inter-American and the UN systems, change has occurred in the sense of excluding civilians from being tried by military courts. ${ }^{57}$ The Court highlighted the apprehension that the applicant must have felt appearing before judges belonging to the army and concluded that military tribunals cannot be deemed independent or impartial in such instances.

In a few Austrian cases, the Court was faced with the question if the Regional Commission - an institution vested with approval powers concerning real estate transfers - was an independent tribunal for the purposes of Article 6(1) ECHR.

In Ringeisen, the applicant's sale concerning a plot of land was blocked by the Regional Commission on the grounds that the applicant intended to use the land for industrial purposes instead of agricultural purposes. ${ }^{58}$ The applicant challenged, in particular, the fact that the Regional Commission was appointed by the local government and was therefore not independent.

53 Belilos v. Switzerland, quoted above, paragraph 66.

54 Belilos v. Switzerland, quoted above, paragraph 67.

55 ECtHR. Ergin v. Turkey (no. 6), application no. 47533/99, judgement of 4 May 2006.

56 Ergin $v$. Turkey, quoted above, paragraph 47.

57 Ergin $\nu$. Turkey, quoted above, paragraphs $21-25$.

$5^{8}$ ECtHR. Ringeisen $v$. Austria, application no. 2614/65, judgement of $16 \mathrm{Jul} 1971$. 
The Court rejected as a matter of principle the allegation that a body appointed by the executive is biased by the sole reason of its appointment. ${ }^{59}$ Without going into a deeper analysis, the Court found that the Regional Commission was simply a tribunal independent from the executive and from the parties that had its members appointed for a five-year mandate and that it was operating on the basis of sufficient procedural guarantees. ${ }^{60}$

Almost a decade later however, the Court considered a similar case and reached a different conclusion. In Sramek, the applicant signed a sales contract concerning a plot of land and made an initial payment to the seller. ${ }^{61}$ The Regional Commission comprised at the relevant time (1) a farmer, who was the mayor of a municipality in the Tyrol, as chairman, (2) a judge of the Innsbruck Court of Appeal, (3) another farmer, sitting as an agricultural expert, (4) a lawyer and (5) three civil servants from the Office of the Land Government, one of whom acted as rapporteur. The Court stated that, with the exception of the three civil servants, no issues concerning independence arose in relation to the other members of the Regional Commission. However, even if no normative incompatibility existed between the requirements of the Convention and the fact that Government nominees sit on tribunals, a problem might arise when the Governmental body becomes a party to the proceedings. Thus, in the applicant's case, the Land Government represented by the Transactions Officer acquired the status of a party when it appealed to the Regional Authority against the first-instance decision in the applicant's favour, and in that the Transactions Officer was the superior one of the three civil servants in question. What was decisive in this case was the fact that the civil servant at issue occupied a key position within the Regional Commission. As rapporteur, he had to set out and comment on the results of the investigation and then to present conclusions. Also, the secretariat for the Regional Commission's meetings was supplied by the department of the Transaction Officer.

The ECtHR noted that it could not

confine itself to looking at the consequences which the subordinate status of the rapporteur vis-à-vis the Transactions Officer might have had as a matter of fact. In order to determine whether a tribunal can be considered to be independent as required by Article 6, appearances may also be of importance. Where, as in the present case, a tribunal's members include a person who is in a subordinate position, in terms of his duties

\footnotetext{
$59 \quad$ Ringeisen v. Austria, quoted above, paragraph 97.

6o Ringeisen $v$. Austria, quoted above, paragraph 95 .

61 ECtHR. Sramekv. Austria, application no. 879o/79, judgement of 22 Oct 1984.
} 
and the organisation of his service, vis-à-vis one of the parties, litigants may entertain a legitimate doubt about that person's independence. ${ }^{62}$

In light of the above, the Court concluded that the Regional Commission was not an independent tribunal for the purposes of the Convention.

\subsubsection{Safeguards}

The ECtHR has considered a variety of safeguards developed by the Member States of the Council of Europe in order to ensure independence of justice.

In the case of Le Compte, Van Leuven and De Meyere, the Court considered that the Appeals Council - an adjudicatory body functioning within the Order of Medical Doctors - was independent due to the equal number of medical practitioners and members of the judiciary sitting on it and to the limited duration of their term of office (six years). ${ }^{63}$

In Piersack, the Court found that Belgian legislation provided for enough guarantees against possible pressure on the court of assize, the most important of which was the strict rules concerning the nomination of the jurors. ${ }^{64}$

In the case Henryk Urban and Ryszard Urban, the applicants were convicted by a single-judge court formed of an assessor for the administrative offense of refusing to disclose their identity to the police. ${ }^{65}$ The Court noted that the assessor at issue could at all times during her mandate be removed by the Minister of Justice and that there were no guarantees against the abusive exercise of this power. The Court held that "it is not necessary to consider other aspects of the status of assessors since their removability by the executive is sufficient to vitiate the independence of the Lesko District Court which was composed of the assessor" ${ }^{66}$ The Court also found that the shortcoming in question could not be rectified on appeal since the appeal court did not have the power to quash the judgment delivered by the assessor. ${ }^{67}$ The Court relied on the findings of the Polish Constitutional Court, concluding that the way in which Poland had legislated the status of assessors was deficient. ${ }^{68}$

\footnotetext{
62 Sramekv. Austria, quoted above, paragraph 42.

63 Le Compte, Van Leuven and De Meyere v. Belgium, quoted above, paragraph 57.

64 ECtHR. Piersackv. Belgium, application no. 8692/79, judgement of 1 Oct 1982, paragraph 27.

65 ECtHR. Henryk Urban and Ryszard Urban v. Poland, application no. 23614/o8, judgement of 3 o Nov 2010.

66 Henryk Urban and Ryszard Urban v. Poland, quoted above, paragraph 53.

67 Henryk Urban and Ryszard Urban v. Poland, quoted above, paragraph 54.

68 Henryk Urban and Ryszard Urban v. Poland, quoted above, paragraphs $5^{\mathrm{O}-52 .}$
} 
The situation of assessors has also been analysed in a few Austrian cases. In Stechauner, the applicant was a practitioner of general medicine. The dispute that arose between the applicant and the Regional Health Insurance Board was heard and decided by the Regional Appeals Commission. ${ }^{69}$ The applicant complained that two assessors sitting for the Regional Appeals Commission were employees of the Regional Health Insurance Boards.

The Court noted that assessors, who have special knowledge and experience in the relevant field, "contribute to a court's understanding of the issue before it and appear in principle to be highly qualified in the adjudication of the disputes. Moreover, the inclusion of lay assessors is a common feature in many countries". ${ }^{70}$ In the applicant's case, however, the Court noted that the assessors were not appointed by the Regional Health Insurance Board, but by the Federal Minister of Justice. In addition, the Austrian legislation forbade employees of the Regional Health Insurance Board to sit as assessors in cases where the defendant is their employer. ${ }^{71}$ The Court found these two elements sufficient for concluding that, in the case at issue, the Regional Appeals Commission was an independent and impartial tribunal. ${ }^{72}$

In Bryan, an enforcement notice was served on the applicant to demolish two buildings that he had allegedly erected in breach of planning legislation. ${ }^{73}$ Upon the applicant's appeal to the Secretary of State for the Environment, an inspector was appointed to perform an investigation and to decide the appeal. Mr Bryan contended that the proceedings which he had brought before a planning inspector to challenge the planning enforcement notice served on him did not comply with Article 6(1) ECHR in that the planning inspector was not independent.

While the Court agreed that the relevant statutory provisions in place required the planning inspector to decide on the applicant's appeal in a quasijudicial, independent, impartial and fair manner, the same provisions gave the right to the Secretary of State to revoke the planning inspector at any stage of the proceedings. The Court held that

in the context of planning appeals, the very existence of this power available to the Executive, whose own policies may be in issue, is enough to

69 ECtHR. Stechaunerv. Austria, application no. 20087/o6, judgement of 28 Jan 2010.

$70 \quad$ Stechauner v. Austria, quoted above, paragaph 55 .

71 Stechauner v. Austria, quoted above, paragaph 58.

72 The same conclusion was reached by the Court in ECtHR. Puchstein v. Austria, application no. 20089/o6, judgement of 28 Jan 2010.

ECtHR. Bryan v. the United Kingdom, application no. 19178/91, judgement of 22 Nov 1995. 
deprive the inspector of the requisite appearance of independence, notwithstanding the limited exercise of the power in practice as described by the Government and irrespective of whether its exercise was or could have been in issue in the present case. For this reason alone, the review by the inspector does not of itself satisfy the requirements of Article 6(1) ECHR, despite the existence of various safeguards customarily associated with an independent and impartial tribunal. ${ }^{74}$

\subsection{Impartiality}

Impartiality is freedom from bias. While it is indeed questionable if freedom from bias is possible at all, in the context of adjudication this is an essential piece of the right to a fair trial that seeks to ensure that the path between the adjudicator and the case is illuminated only by the facts, the evidence and the adjudicator's reasoning. ${ }^{75}$ These three elements are all prone to manipulation during a trial; the facts and the evidence appear as they are presented by the parties and the adjudicator's reasoning will be influenced by his legal education, personal preferences and background. However, impartiality as a procedure of the fair trial principle accepts the facts, the evidence and the adjudicator's reasoning as the basis for delivering a justice system that creates confidence and social cohesion.

Despite its central role, impartiality is not an easy concept to measure as it requires the assessment of the adjudicator's behaviour in the courtroom, but also, of his moral preferences and of his inner life. This is both an intrusive and a difficult exercise that can sometimes lead to approximate results. This is, furthermore, a complicated test to perform for an international tribunal such as the ECtHR. The ECtHR recognizes this and cases concerning impartiality are rare and often linked to the related notion of independence. Also, when the ECtHR performs the impartiality test on its case-law, it borrows notions used to assess the independence of courts.

\subsubsection{Prior Involvement with the Case}

The question of impartiality is often raised before the ECtHR in cases where the adjudicator has been previously involved with the case.

74 Bryan $v$. the United Kingdom, quoted above, paragraph 38.

75 Beignier, Bernard and Corinne Bléry. "L'impartialité du juge, entre apparence et réalité." Recueil Dalloz, Chronique (2001): pp. 2427-2433. 
Hauschildt was one of the earliest cases at the ECtHR in which the Court was faced with the question of the impartiality of a tribunal. The applicant criticized the Danish judiciary system whereby a judge was entrusted with a supervisory role in the investigation process and was later expected to conduct the trial "with a mind entirely free from prejudice". ${ }^{76}$

The Court noted that "this kind of situation may occasion misgivings on the part of the accused as to the impartiality of the judge, misgivings which are understandable, but which nevertheless cannot necessarily be treated as objectively justified. Whether they should be so treated depends on the circumstances of each particular case". 77

In Fey, the applicant complained that the district court judge had both undertaken preliminary investigations and tried his case. ${ }^{78}$ Further, the applicant complained that the regional court judges who had rejected his request for release were subsequently called upon to rule on his appeal.

The Court undertook a detailed analysis of the tasks performed by the case judge during the pre-trial investigation. These tasks included collecting information, transmitting the case-file to the Innsbruck District Court so that it could put further questions to the applicant and setting the case down for trial.

The Court stated that impartiality can be determined according to a subjective test, that is on the basis of the personal conviction of a particular judge in a given case, and according to an objective test, that is ascertaining whether the judge offered guarantees sufficient to exclude any legitimate doubt in this respect. ${ }^{79}$

The Court noted that, as a matter of principle, the mere fact that a judge has made pre-trial decisions in a case is not sufficient to ground the fear of impartiality. What is decisive is the extent and the nature of those measures.

The Court concluded, however, that the various measures taken prior to the trial by the judge deciding the case were not such as could have led her to reach a preconceived view on the merits. The Court especially highlighted the fact that the judge under consideration acquitted the applicant on one of the two accounts. ${ }^{80}$

In Fatullayev, the applicant was a journalist who, after publishing two articles concerning the Khojaly massacre, was convicted of terrorism and ordered to pay civil damages. ${ }^{81}$ He complained that the judge who had examined

76 Hauschildt v. Denmark, quoted above, paragraph 43.

77 Hauschildt v. Denmark, quoted above, paragraph 48.

78 ECtHR. Fey v. Austria, application no. 14396/88, judgement of 24 Feb 1993.

79 Feyv. Austria, quoted above, paragraph 28.

8o Fey v. Austria, quoted above, paragraphs $32-35$.

81 ECtHR. Fatullayevv. Azerbaijan, application no. 40984/o7, judgement of 22 Apr 2010. 
allegations against him in the context of a civil action could not have an impartial position when examining the same allegations in the criminal context.

The Court noted that as a matter of principle, a situation where the same judge examines the questions of both civil liability and criminal liability arising from the same facts does not necessarily affect the judge's impartiality. However, on the facts of the case, the Court considered that having decided the civil case against the applicant, the judge had already given an assessment to the applicant's statements and, more importantly, had qualified those facts as false information that defamed the survivors of the Khojaly massacre. Under these circumstances, doubts could be legitimately raised as to the appearance of impartiality of the same judge who was later called to give his opinion about the same allegedly defamatory statements, but in a criminal context. ${ }^{82}$

In Elezi, the applicant complained about the impartiality of the lay judges because they were provided a copy of the bill of indictment that contained the prosecution's main findings. ${ }^{83}$ The Court noted the findings of the domestic courts that the bill of indictment should not be disclosed to the lay judges as they risked mixing up the prosecution evidence with the matters from the main hearing. ${ }^{84}$ The Court noted however that, after the bill of indictment was presented to the lay judges, twenty more hearings were held in the applicant's case and that the applicant did not raise an objection concerning the impartiality of the lay judges in the domestic proceedings. On the basis of this, the Court found that the applicant's fear as to the lay judges' impartiality could not be justified objectively. 85

An interesting issue was raised in the case Perus, where the applicant was involved in a long-standing employment dispute. ${ }^{86} \mathrm{He}$ complained that one of the judges involved in the proceedings concerning his appeal on points of law could not be considered impartial because of his prior involvement in the case as a judge of the Higher Court. The Court noted that nine years had elapsed between the date of the judgement adopted by the Higher Court's panel presided over by judge L.F. and the judgement of the panel of the Supreme Court of which judge L.F. was a member. The Court drew attention to the fact that, despite the long period of time between the different parts of the proceedings, judge L.F. played very important roles at different levels of jurisdiction: he was

82 Fatullayev v. Azerbaijan, quoted above, paragraphs 138-140.

83 ECtHR. Elezi v. Germany, application no. 26771/o3, judgement of 12 Jun 2008.

84 Elezi v. Germany, quoted above, paragraph 47.

85 Elezi v. Germany, quoted above, paragraphs $5^{1-54}$.

86 ECtHR. Perus v. Slovenia, application no. 35016/o5, judgement of 27 Sep 2012. 
the presiding judge in the Higher Court's panel and he was the judge rapporteur during the proceedings before the Supreme Court.

The Court concluded that there was no indication in the case-file that judge L.F. was aware of or remembered her prior involvement in this particular case. It observed, however, that there was "a risk of problems arising in a system which lacks safeguards to ensure that the judges are reminded of their prior involvement in particular cases, above all where such matters rely on the judges' own assessment". ${ }^{77}$

\subsubsection{Expression of Views}

Impartiality can also be at issue when the adjudicator expresses publicly views about the outcome of the case before the case is settled.

In Olujic, the applicant was a judge and the former President of the Supreme Court. ${ }^{88}$ Disciplinary proceedings were conducted against the applicant by the National Judicial Council (NJC) for having socialized in public places with two individuals who had criminal backgrounds. As a result of the disciplinary proceedings, the applicant was dismissed from the office of judge and from that of President of the Supreme Court. The applicant complained that the three members of the NJC were not impartial since they had expressed opinions against him in the national newspapers during the disciplinary proceedings.

The Court noted that all three members of the NJC, including its president, publicly used expressions that implied they had already formed an opinion about the applicant's guilt before the finalization of the proceedings. In addition, the statements were such as to justify the applicant's fears as to their impartiality. ${ }^{89}$ The Court found therefore a breach of Article 6(1) ECHR.

In a case involving the gaming industry in the United Kingdom, the Court was called to decide if the Gaming Board was an independent and impartial tribunal..$^{90}$ In that case, the applicant was the sole executive director of a company managing six of the twenty casinos licenced to operate in London. Following a raid by the Gaming Board, the applicant's employment contract was terminated. In addition, the president of the Gaming Board had publicly stated during an industry lunch that the applicant was not a fit and proper person to exercise the function of an executive director. Later, the Gaming Board initiated special proceedings - called Section 19 proceedings - to deprive the

$87 \quad$ Perus v. Slovenia, quoted above, paragraph 39.

88 ECtHR. Olujic v. Croatia, application no. 22330/o5, judgement of 5 Feb 2009.

89 Olujic v. Croatia, quoted above, paragraphs 62-67.

$90 \quad$ Kingsleyv the United Kingdom, quoted above. 
applicant of the right to exercise managerial functions in the gaming industry in the UK and affiliated jurisdictions.

The Court noted that it appeared from the facts of the case that the Gaming Board had already formed the opinion that the applicant was not a fit and proper person before a hearing was held in this case. The three members who subsequently adjudicated the Section 19 proceedings against the applicant were all present and voted in favour of the decision of the Gaming Board that the applicant was not a fit and proper person to be a casino director. The Court concluded that for this reason the panel hearing this dispute did not present the necessary appearance of impartiality as required by Article 6(1) ECHR. ${ }^{91}$

\subsection{The Relevance of the ECtHR's Case-Law on Independence and Impartiality}

Two main questions should guide the modern debate about the independence and impartiality of justice. First, is independence an end in itself or should it be pursued in order to achieve other goals, and if so, which other goals? Second, should the approach to independence be holistic or atomistic? These questions are particularly important for the conversation surrounding the independence of administrative justice. Thus, for example, pursuing independence for the purpose of achieving efficiency is a different effort from pursuing independence for the purpose of trust-building or maintaining a healthy separation of powers. Also, an approach to independence wherein one safeguard can render an administrative tribunal independent is a different approach from conceiving an administrative process that ensures independence as a whole.

The case-law of the ECtHR on independence and impartiality appears to be well-equipped to answer these questions and to inform the modern constitutional debates outlined at the beginning of this chapter concerning the independence of administrative justice. The ECtHR initially formulated the principles concerning the interpretation of the notions of independence and impartiality in criminal cases. Over the years, however, the same principles have been successfully applied to administrative disputes covering various issues facing the citizen and the state. Irrespective of the disputed judicial formations - assessors, single-judge courts, Supreme Administrative Courts or even the Crown in the UK - and of the types of disputes - land planning disputes, medical disputes, banking disputes or disputes concerning the financial 
markets - the ECtHR maintained that Article 6(1) ECHR required tribunals to be independent and impartial.

Article 6(1) ECHR requires three conditions to be satisfied for a tribunal to be deemed compatible with the Convention: the tribunal must be established by law, it must be independent and it must be impartial. The ECtHR highlights that its goal is not to impose upon the states a constitutional model concerning the relationship and interaction of different state powers. ${ }^{92}$ However, the ECtHR's case-law on independence and impartiality appears to achieve the opposite. In relation to the condition that a tribunal must be established by law, the ECtHR found that a tribunal compatible with Article 6(1) ECHR must be established respecting a constitutional chain of delegation: citizens choose the parliament or vote for the constitution, the parliament or the constitution establish tribunals and tribunals deliver justice to citizens. In addition, a tribunal established by law must also specifically be endowed with a judicial function.

Independence is a concept dealing with external features of the judiciary and it requires a constitutional setup whereas other branches of the government do not encroach on the performance of justice. From this point of view, independence acts like a fence. Impartiality, on the other hand, is a concept that deals with the internal and intimate features of the judiciary, describing both the peer relationships within the judiciary, and also the relationship that a judge has with his own beliefs. Impartiality thus describes what should take place inside the fence. Although the ECtHR maintains the distinction between independence and impartiality, sometimes it uses them interchangeably.

Based on the case-law described above, I suggest that, when assessing the independence and impartiality of an administrative tribunal, the ECtHR takes into account four elements: (1) cumulation of functions, (2) safeguards, (3) appearances and (4) availability of judicial review. These elements are often interlinked.

A salient feature of administrative tribunals is the concomitant exercise of investigative, prosecutorial and adjudicative functions. Since the ECtHR requires two fresh eyes and a fresh brain to perform decision-making tasks, tribunals that cumulate functions would a priori be contrary to Article 6(1) ECHR because of the pre-formed opinions that the decision-makers would have gathered. This is not an absolute rule, however, and the ECtHR elegantly qualifies it. On the one hand, cumulation of functions is starkly visible and can easily offend the sense of justice of a citizen involved in trial against the state. On the 
other hand, the ECtHR distinguished in Didier between simple case-handling functions such as checking the facts and reporting on them and more offensive forms of cumulation of functions that would combine the formulation of charges with the power to close cases or extend investigations. ${ }^{93}$ In the same vein, the ECtHR showed in Dubus s.A. that both legal texts and internal regulations of the banking industry should clearly separate the tasks of prosecution from taking evidence and from adjudication. ${ }^{94}$

The case-law of the ECtHR on independence and impartiality pays close attention to the safeguards engrained in the analysed systems. The ECtHR has pointed out that clear rules concerning the appointment and removability of adjudicators by the executive, the presence of technical specialists alongside generalists on specialized tribunals, and internal rules concerning the separation of functions contribute to a tribunal's independence and can prevent abuses during the trial.

Three general ideas can be deduced from the case-law analysed above. First, lack of individual independence can be compensated for by strong fair trial guarantees during the trial or corrected during judicial review. Thus, if an adjudicator has been previously involved with a case, posing thus a threat to independent adjudication, rules of procedure concerning the disclosure of the previous involvement or the change in the bench, may suffice to compensate for the lack of independence. Also, the appeal court, may assess the alleged lack of independence, reconsider the case independently or re-send the case to the concerned adjudicator. In any case, what is important is that the procedure as a whole allows for the assessment and correction of the lack of independence.

The second idea deduced from the case-law of the ECtHR is that structural lack of independence canneither be compensated, nor corrected byjudicialreview. Indeed, judicial review can play a role as a safeguard for the independence of justice only when the lack of independence is personal, not structural. For example, as Beaumartin highlighted, there are instances when judicial review cannot remedy the lack of independence of an administrative procedure due to the deference shown during judicial review to the administrative authority at issue. ${ }^{95}$ In other words, deference by a court to an administrative authority performing judicial functions that lacks independence is not compatible with the right to a fair trial.

Finally, it appears that the ECtHR proposes a relationship of direct proportionality between the consequences of the lack of independence and

93 Didier v. France, quoted above.

94 Dubus S.A. v. France, quoted above.

95 Beaumartin v. France, quoted above. 


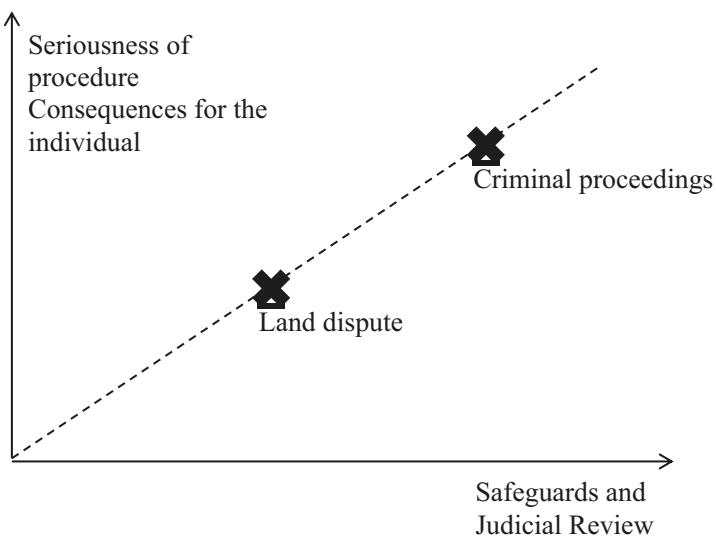

FIGURE 9 Relationship between seriousness of consequences of a given procedure and existing safeguards or judicial review

the existing safeguards, including the availability of judicial review. In Sigma Radio, the ECtHR found that the fines imposed by an administrative authority cumulating prosecutorial and adjudicative functions were used to pay the salaries of the administrative authority's employees. ${ }^{96}$ In Campbell and Fell, the ECtHR took note of the fact that the disciplinary measures applied by the Board of Visitors - a body having overlapping supervisory and adjudicatory functions - delayed the defendants' release from prison by two years. ${ }^{97}$

As Figure 9 above suggests, when a procedure has serious consequences for the individuals affected, courts or tribunals should be able to perform effective judicial review.

Independence and impartiality are intimately linked to the design of the justice-imparting institutions and their procedures. The duty of independence is thus individual, behavioural and systemic. Individual adjudicators are required to act independently and impartially. However, this is not sufficient. The design of the justice system must be construed to support institutional, procedural and financial independence at all stages and to correct the lack of independence through judicial review.

To conclude, I suggest that the protective attitude of the ECtHR towards the judicial function in Europe - irrespective of the fact that this function is performed in a court or an administrative tribunal - indicates that the ECtHR embraces a holistic approach towards independence. Administrative justice

$96 \quad$ Sigma Radio Television Ltd. v. Cyprus, quoted above.

97 Campbell and Fell v. the United Kingdom, quoted above. 
should be imparted independently, and the standards that the ECtHR uses for this purpose do not differ from the standards applied for classical court proceedings. However, procedural defects that affect the independence of administrative proceedings should be corrected during the process of effective judicial review.

In the following chapters, I endeavour to analyse how these precepts are reflected in the work of the EU Commission as enforcer of EU competition law. 